\title{
The Medicinal Significance of Datura stramonium: A Review
}

\author{
Reema Srivastava $^{1 *}$ and Pankaj Srivastava ${ }^{2}$ \\ ${ }^{1}$ Department of Botany, Jaipur, India \\ ${ }^{2}$ Department of Surgery, Varanasi, India
}

*Corresponding author: Reema Srivastava, Assistant Professor, Department of Botany, Kanoria PG Mahila Mahavidyalaya, Jaipur, India

ARTICLE INFO

Received: 㓞 July 15, 2020

Published: 幽 July 28, 2020

Citation: Reema Srivastava, Pankaj Srivastava. The Medicinal Significance of Datura stramonium: A Review. Biomed J Sci \& Tech Res 29(2)-2020. BJSTR. MS.ID.004761.
ABSTRACT

Datura stramonium is commonly known as thorn apple belongs to family Solanaceae. Itis a wild plant having various medicinal and pharmacological properties. Alkaloids, atropine, scopolamine, tannin, saponin, glycosides, phenol, sterols, lignin, fats, carbohydrates and proteins are different compounds present in Datura. Datura stramonium have antiepileptic, anti-asthmatic, analgesic, antioxidant, antimicrobial, insecticidal, repellent and organophosphate protective effects. The present review is focused on the phytochemical and pharmacological studies of the Datura stramonium.

Keywords: Datura Stramonium; Medicinal Plant; Phytochemistry; Pharmacological Activities; Traditional Uses

\section{Introduction}

Datura stramonium (DS) is an annual plant belongs to the family Solanaceae. It originates in the America but is found around the world including North, Central and South America, Europe, Asia and Africa [1]. Datura stramonium is a foul smelling, erect, free branching herb that forms a bush up to 2-5 feet tall. The root is long thick, fibrous and white. It has simple or bifurcated round, erect, glabrous stem. The leaves are $8-20 \mathrm{~cm}$ long, smooth, toothed, soft and irregularly undulated. The leaves have a bitter and nauseating taste, which is imparted to extracts of the herbs and remains even after the leaves have been dried. Flowers are large, white, solitary and terminal. Fruit is $5 \mathrm{~cm}$ long, four valve capsules, which is densely thorny and walnut sized. At maturity it splits into four chambers, each with dozens of seeds. Seeds are long, flat, reniform and black [2-7]. The genus Datura comprises all the nightshades and agricultural plants including potato, S. tuberosum, Lycopersicon, Coffeaarabica and pepper. Classification of different species within Datura genus relies heavily on genetic markers, which suggest that this genus has huge variation due to mutation [8-10].

Datura stramonium has long been known for its hallucinogenic and euphoric effects. It was dried and smoked for hallucination and total relaxation $[1,11]$. It is toxic when consumed improperly. Accidental poisoning of humans and animals, who consume food sources contaminated with $D$. stramonium has been reported. In areas where millet, wheat, rye, corn and bean seeds are used for human consumption and where D. stramonium is a common weed, the grain sometimes has been contaminated with Datura seeds. The large amount of Datura affects the central nervous system with symptoms such as confusion, bizarre behavior, hallucinations and subsequent amnesia [12-13]. Therefore, a thorough understanding of the possible pharmacological and toxicological effects of $D$. stramonium is needed. The review presents the major medicinal uses of Datura stramonium, discovered through last many years of research in animals and human subjects as well as in the other experimental studies.

\section{Phytochemistry}

D. stramonium contains sixty-four different types of tropane alkaloids. The major tropane alkaloids hyoscyamine and scopolamine and several minor tropane alkaloids have been identified in Datura species. Thealkaloids scopoline, 3-(hydroxyacetoxy) tropane, 3-hydroxy-6-(2-methylbutyryloxy) 
tropane,3a-tigloyloxy-6-hydroxytropane, 3,7- dihydroxy6-tigloyloxytropane, 3-tigloyloxy-6-propionyloxytropane, 3-phenylacetoxy-6,7- epoxytropane, 3-phenylacetoxy-6-hydro xytropane,aponorscopolamine, 3a,6a-ditigloyloxytropane and 7-hydroxyhyoscyamine are reported for the first time by Berkov et al. [14]. Sterols and there derivatives [5.alpha.-Ergosta-7,22- dien3.beta.-ol (16.53\%), 3-Hydroxycholestan-5-yl,acetate (14.97\%), and 26,26-Dimethyl-5, 24(28)-ergostadien-3.beta.-ol (10.39\%)] are the major constituents of essential oil of Datura stramonium. The primary biologically active substances in D. stramonium are the alkaloids atropine and scopolamine Ivancheva [15]. The aqueous and ethanolic extract of the stem-bark of Datura stramonium contained alkaloids, saponins, tannins, steroids, flavonoids, phenols and glycosides. Alanine, glutamate, phenylalanine, tyrosine and many other amino acids were isolated from the seeds. The tropane alkaloids were the important anticholinergic alkaloids isolated from Datura stramonium. The highest content of alkaloid are present in the vegetative and generative phases of leaves and capsules, respectively. Generally, the younger parts of plants contained more alkaloids than older ones. Alkaloid content decreased rapidly in leaves in the generative phase. Scopolamine was lowest $(0.013 \%)$ in roots in the vegetative period, and then totally disappeared in the generative period. Atropine present in roots in both the vegetative $(0.045 \%)$ and generative $(0.056 \%)$ periods. Stems were rich in atropine $(0.070 \%)$ but poor in scopolamine $(0.023 \%)$ in both stages [16-19]. The maximum contents of atropine are found in the stems leaves and seeds. The maximum contents of hyoscyamine and scopolamine are found in the stems and leaves of young plants, hyoscyamine being always the predominant component.

\section{Traditional Use of Datura Stramonium}

The World Health Organization (WHO) estimates that four billion people, about $80 \%$ of the world's population presently use herbal medicine for some aspect of primary health care. Plants generally produce many secondary metabolites which were constituted an important source of many pharmaceutical drugs [20-21]. In Ayurvedic medicine, D. stramonium is described as a useful remedy for various human ailments including ulcers, wounds, inflammation, rheumatism and gout, sciatica, bruises and swellings, fever, asthma, bronchitis and toothache. Many folk medicine remedies use D. stramonium therapeutically [22]. The juice of the leaves in warm milk was used to expel intestinal worms including cestodes, seeds with palm oil used externally for insect bites and stings insects. When the leaves of Datura stramonium mixed with mustard oil then it is useful in skin disorders. Juice of flower petals is used in ear pain and seeds are used as purgative, in cough, fever and asthma. Seeds are smoked due to its narcotic action [23-24]. In Western Nepal, leaves of Datura along with the leaves of Cannabis sativa and stem of Neopicrorhizascrofulariflora, are pounded with water and applied to treat headaches. Datura seeds are crushed with grains of rice and taken orally to relief in indigestion. In parts of Central Nepal fresh leaves are warmed and placed on a sprained body part repeatedly, before going to bed, for the alleged analgesic effect. In India, seeds are used as a tonic and febrifuge. The leaves are roasted and applied locally to relieve pain [25]. Native Americans used Datura seeds for many years as a euphoric agent. Since the 1800s, it was used as a therapeutic agent in Great Britain [26].

\section{Pharmacological Activities}

\section{Organophosphate Poisoning (OP)}

DS contains atropine and other anticholinergic compounds and it is very useful remedy for the central cholinergic symptoms of OP. Bania et al [27] reported the beneficial effects of DS seed extracts following a severe OP. According to their experiment, DS seeds were heated in water to make $2 \mathrm{mg} / \mathrm{ml}$ atropine solution and administrated to male rats as a single intraperitoneal injection $5 \mathrm{~min}$ before the subcutaneous injection of $25 \mathrm{mg} / \mathrm{kg}$ of dichlorvos. Pretreatment with Datura seed extract significantly increased survival in a rat model of severe OP.

\section{Antiepileptic Effects}

According to Peredery and Persinger [28], rats were continuously administrated one of 3 herbal treatments $S$. lateriflora, G. sempervirens and D. stramonium through water supply for 30 days, one week after the induction of status epilepticus by a single injection of lithium $(3 \mathrm{mEq} / \mathrm{kg})$ and pilocarpine $(30 \mathrm{~g} / \mathrm{kg})$. The number of spontaneous seizures per day during a $15 \mathrm{~min}$ observation interval was recorded for each rat during the treatment period and during an additional 30 days when only tap water was given. Rats that received a weak solution of the three herbal fluid extracts displayed no seizures during treatment. However, when this treatment was removed, the rats displayed numbers of spontaneous seizures comparable to the controls.

\section{Antimicrobial Activity}

The methanol extracts of aerial part of DS showed the bactericidal activity against gram positive bacteria in a dose dependent manner [29]. Sharma et al. [30], suggested that DS was very effective as vibriocidal against various strains of Vibreo cholera and Vibreo parahaemolyticus. The minimum inhibitory concentration (MIC) value of acetone extracts of DS was in the range of $2.5-15 \mathrm{mg} / \mathrm{ml}$ serving as broad spectrum vibriocidal agents.

\section{Anti-Asthmatic Activity}

D. stramonium contains a variety of alkaloids, including atropine and scopolamine, having an anticholinergic and broncho dilating activity. Atropine and scopolamine act on the muscarinic receptors by blocking them (particularly the M2 receptors) on airway smooth muscle and submucosal gland cells, which dilate bronchial smooth muscle and ease asthmatic attacks. Charpin et al. [31] reported that using $D$. stramonium as an antiasthmatic, cigarette is an effective bronchodilator in asthmatic patients with mild airway obstruction. 
However, the exposure of $D$. stramonium to the fetus when a mother uses it for asthma will cause a continuous release of acetylcholine, resulting in the desensitizing of nicotinic receptors, which could ultimately result in permanent damage to the fetus [32].

\section{Analgesic Activity}

The analgesic effect of alcoholic Datura seed was evaluated in acute and chronic pain using hot plate and formalin tests. The extracts when intraperitonealy administrated to the animals, they, dose dependently alleviated the pain, and ED50 was 25 and 50mg/ $\mathrm{kg}$ in hot plate and formalin tests, respectively [33].

\section{Antifungal Activity}

According to Mdee et al. [34], the fungicidal effects of the acetone extracts indicate the potential of DS seeds as a natural source of antifungal agent. The MIC of DS extracts ranges from 1.25$2.50 \mathrm{mg} / \mathrm{ml}$.

\section{Anticancer Activity}

D. stramonium was reported to have anticancer effect against human epidermal carcinoma of the nasopharynx at a therapeutic dose of 0.05 to $0.1 \mathrm{~g}$. However, precaution should be taken while using Datura as an anticancer agent since adverse anticholinergic effects may occur [35].

\section{Infertility in Women}

Datura flowers are effective treatment of infertility in women. The dried powder of Datura flowers in dosage of $120 \mathrm{mg}$ is given with honey 10 days after menstruation. It is given for 5 to 7 days. This remedy is effective in infertility of unknown reason [36].

\section{Insecticidal Activity}

Datura plant generates a characteristic odor thatacts as repellent for various insects and pests. Kurnal, et al. [37] have reported that the ethanol extracts of $D$. stramonium leaf and seed showed potent acaricidal, repellent, and oviposition deterrent activity against adult two-spotted spider mites (Tetranychusurticae) under laboratory conditions. Leaf and seed extracts which were applied in 167.25 and $145.75 \mathrm{~g} / \mathrm{L}$ concentrations (using a Petri leaf disc-spray tower method), caused $98 \%$ and $25 \%$ mortality among spider mite adults after $48 \mathrm{~h}$, respectively. These results suggest that $D$. stramonium could be used to manage the two-spotted spider mite.

\section{Dosage}

DS is generally administrated at a dose of $60-185 \mathrm{mg}$ powder for leaf and 60-120mg powder for seed [38].

\section{Conclusion}

Plants are used as for food, shelter, fiber, tan, gum, oil, latex etc. They are rich source of nutrients, antioxidants, vitamins, carbohydrates, proteins, due to this; they also contributed immunomodulatory effect. This review concluded that Datura stramonium is a wild plant having various medicinal and pharmacological properties and these properties exploited for cancer, rheumatism, ear pain, headache, wound, burn, stress, depression, insomnia, asthma, boils, and inflammation. Datura stramonium, exhibits pharmacological effect and prepared as herbal or botanical drugs by pharmaceutical industries for many diseases, but not used in native form because of its lethal effect.

\section{References}

1. Bayih T (2014) Synergistic bio-eficacy of insecticidal plants against bean bruchids (Zabrotessubfasciatus: Coleoptera) a major storage pests of common bean (Phaseolus vulgaris L.) in central rift valley of Ethiopia. MSc thesis, Department of Biology, School of Graduate Studies, Haramaya University.

2. Soni P, Siddiqui AA, Dwivedi J, Soni V (2012) Pharmacological properties of Datura stramonium L. asa potential medicinal tree: An overview. Asian Pac J Trop Biomed 2(12): 1002-1008.

3. Li J, Lin B, Wang G, Gao H Qin M (2012) Chemical constituents of Datura stramonium seeds. China Journal of Chinese material 37(3): 319-322.

4. Usha K, Singh B, Praseetha P, Deepa N, Agarwal DK, et al. (2009) Antifungal activity of Datura stramonium, Calotropisgigantea and Azadirachtaindica against Fusarium mangiferae and malformation in mango, European Journal of Plant Pathology 124: 637-657.

5. Olofintoye LK, Simon IA, Omoregie OB (2011) Larvicidal properties of Datura stramonium (Jimson weed) and Nicotianatabaccum extracts against the larvae of (Anopheles and Culex) mosquitoes. African research review V 5(2): 337-344.

6. (2000) PDR for Herbal Medicines. Medical Economics Company, Inc. at Montvale pp. 436-437.

7. Tostes RA (2002) Accidental Datura stramonium poisoning in a dog. Veterinary and Human Toxicology 44(1): 33-34.

8. Fornoni J, Núñez-Farfán J (2000) Evolutionary ecology of Datura stramonium: genetic variation and costs for tolerance to defoliation. Evolution 54(3): 789-797.

9. Luna-Cavazos M, Bye R (2011) Phytogeographic analysis of the genus Datura (Solanaceae) in continental Mexico. Rev Mex Biodivers 82(3): 977-988.

10. Gaire BP, Subedi L (2013) A review on the pharmacological and toxicological aspects of Datura stramonium L.Journal of Integrative Medicine 11(2): 73-79.

11. Williams DG (2013) Larvicidal potential of the leaf extract of Datura stramonium and Occimumgratissimum against Culexquinquefasciatus mosquito species. MSc thesis, Faculty of Science, Amadu Bello UniversityZaria.

12. Naude TW, Gerber R, Smith RJ, Botha CJ (2005) Datura contamination of hay as the suspected cause of an extensive outbreak of impaction colic in horses. Journal of the South African Veterinary Association 76(2): 107112.

13. Norton S (2008) Toxic effects of plants. In: Klaassen CD. Caserett and Doull's toxicology, the basic science of poisons. 7th ed. New York: McGraw Hill pp. 1110.

14. Berkov S, Zayed R, Doncheva T (2006) Alkaloid patterns in some varieties of Datura stramonium. Fitoterapia 77(3): 179-182.

15. Ivancheva S, Nikolova M, Tsvetkova R (2006) Pharmacological activities and biologically activecompounds of Bulgarian medicinal plants. Phytochemistry: Advances in Research pp. 87-103.

16. Shagal MH, Modibbo UU, Liman AB (2012) Pharmacological justification for the ethnomedical use of Datura stramonium stem-bark extract in treatment of diseases caused by some pathogenic bacteria. Int Res Pharm Pharmacol 2(1): 16-19. 
17. Lewis OAM, Nieman E, Munz A (1970) Origin of amino acids in Datura stramonium seeds. Ann of Bot 34(4): 843-848.

18. Robbers JE, Speedie MK, Tyler VE (1996) Pharmacognosy and Pharmacobiotechnology. Williams and Wilkins, Philadelphia.

19. Iranbakhsh A, Oshaghi MA, Majd A (2006) Distribution of atropine and scopolamine in different organs and stages of development in Datura stramonium L. (Solanaceae). Structure and ultrastructure of biosynthesizing cells. ActaBiologicaCracovensia, Series Botanica 48(1): 13-18.

20. Snafi AE Medicinal properties of Datura fastuosa (syn: Datura metel) and Datura Stramonium-A review. IOSR Journal of Pharmacy 7(2): 43-58.

21. Davidson-Hunt I (2000) Ecological ethnobotany: stumbling toward new practices and paradigms. MASA J 16: 1-13.

22. Kirtikar KR, Basu BD (1999) Indian medicinal plants. $2^{\text {nd }}(E d n)$. Volume III. Dehradun: International Book Distributors pp. 1783-1787.

23. Egharevba RKA, Ikhatua MI (2008) Ethno-medical uses of plants in the treatment of various skin diseases in Ovia North East, Edo State, Nigeria. Res J AgricBiolSci 4(1): 58-64.

24. Khan J, Khan R, Qureshi RA (2013) Ethnobotanical Study of Commonly Used Weeds of District Bannu, Khyber Pakhtunkhwa (Pakistan). Journal of Medicinal Plants Studies 1(2): 1-6.

25. Gorsi MS, Shahzad R (2002) Medicinal uses of plants with reference to the people of Dhirkot, Azad Jammu and Kashmir. Asian J Plant Sci 1(3): 222-223.

26. Rajbhandari KR (2001) Ethnobotany of Nepal. Kathmandu: Kishor Offset Press Private Limited 142-143.

27. Bania TC, Chu J, Bailes D, O’Neill M (2004) Jimson weed extract as a protective agent in severe organophosphate toxicity. AcadEmerg Med 11(4): 335-338.

28. Peredery 0, Persinger MA (2004) Herbal treatment following postseizure induction in rat by lithium pilocarpine: Scutellarialateriflora

ISSN: $2574-1241$

DOI: 10.26717/BJSTR.2020.29.004761

Reema Srivastava. Biomed J Sci \& Tech Res

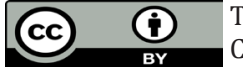

This work is licensed under Creative Commons Attribution 4.0 License

Submission Link: https://biomedres.us/submit-manuscript.php
(Skullcap), Gelsemiumsempervirens (Gelsemium) and Datura stramonium (Jimson Weed) may prevent development of spontaneous seizures. Phytother Res 18(9): 700-705.

29. Eftekhar F, Yousefzadi M, Tafakori V (2005) Antimicrobial activity of Datura innoxia and Datura stramonium. Fitoterapia 76(1): 118-120.

30. Sharma A, Patel VK, Chaturvedi AN (2009) Vibriocidal activity of certain medicinal plants used in Indian folklore medicine by tribals of Mahakoshal region of central India. Indian J Pharmacol 41(3): 129-133.

31. Charpin D, Orehek J, Velardocchio JM (1979) Bronchodilator effects of antiasthmatic cigarette smoke (Datura stramonium). Thorax 34(2): 259-261.

32. Pretorius E, Marx J (2006) Datura stramonium in asthma treatment and possible effects on prenatal development. Environ ToxicolPharmacol 21(3): 331-337.

33. Khalili Najafabadi M, Atyabi SM (2004) Evaluation of analgesic effect of Datura stramonium seed extract in hot plate and formalin tested on male rats. I. J Med and Arom Plants 20(3): 309-322.

34. Mdee LK, Masoko P, Eloff JN (2009) The activity of extracts of seven common invasive plant species on fungal phytopathogens. South African Journal of Botany 75(2): 375-379.

35. Balachandran P, Rajgopal G (2005) Cancer-an Ayurvedic perspective. Pharmacol Res 51(1): 19-30.

36. Kadam SD, Chavhan SA, Shinde SA, Sapkal PN (2018) Pharmacognostic review on Datura. Int. J. Pharmacogn Chinese Med 2(4): 000145.

37. Kurnal NA, Çobanoğlu S, Yalcin C (2010) Acaricidal, repellent and oviposition deterrent activities of Datura stramonium L. against adult Tetranychusurticae (Koch). J Pest Sci 83(2): 173-180.

38. Khare CP (2007) Indian medicinal plants. Delhi: Rajkamal Electric Press: 203.

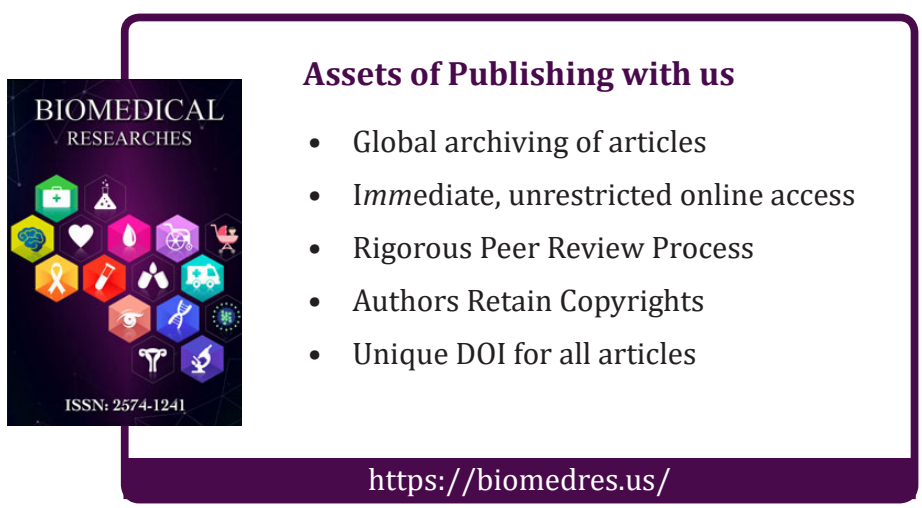

